\title{
OPPORTUNITIES FOR THE REGIONAL UNIVERSITY IN DECREASING EMIGRATION
}

\author{
Irēna Silineviča \\ Dr.sc.ing., professor at the Faculty of Economics and Management, \\ Rezekne Higher Education Institution, Rezekne, Latvia, \\ e-mail: irena.silinevica@ru.lv, phone: +37129103480
}

\begin{abstract}
The trend in the decreasing number of inhabitants is a very significant regional problem in Latvia. During recent years many people of Latvia have emigrated as economic refugees to Ireland, the United Kingdom, Germany and other countries. More than 30\% of them are well-educated young people who gained higher education in Latvia. Most of them are employed as unskilled labourers there. The potential causes of emigration of well-educated young people are analysed in this research study. The aim of the research study is to reveal potential emigration problems of the young generation and to research some opportunities for the regional university in decreasing youth emigration. Potential emigration problems are identified by using findings of a survey of students, organized at Rezekne University of Applied Sciences. The suggestions about opportunities for the regional university in decreasing youth emigration were developed by taking into account the results of the survey and cooperation possibilities between the regional university and municipalities and by changing the approach to the study process.
\end{abstract}

Keywords: emigration, regional development, regional university

JEL code: $R 11, R 23$

\section{Introduction}

The trend in decreasing number of inhabitants in Latvia's regions and overall in Latvia is critical in the context of economic development in Latvia and in the context of existence of the Latvian nation in general. This fact raises concerns related to the simulataneous reduction of intellectual potential in Latvia because approximately one third of emigrants from Latvia are well-educated young people who gained higher education in Latvia. Many researchers have studied emigration problems in Latvia. They are as follows: Kaktinšs, Eglìte, Hazans, Krišjāne, Bauls, Indāns, Lulle, Philips, Bērziñš, Mežs, Dzenovska, etc.

Findings of the researchers about the emigration problems in Latvia before the economic crisis allowed defining the groups of inhabitants which, with higher probability, would be able to leave the country as economic refugees. These groups were young people at the age of $15-$ 24. Findings of the research about emigration problems in Latvia after the economic crisis showed that $80 \%$ of the emigrants who had emigrated during the economic crisis were younger than 35 years and most of them were highly educated. Results of the survey of students, 
conducted in 2011, indicated that $65 \%$ of the students planned to live and work abroad after their graduation (Hazans, 2011).

The aim of this research study is to reveal some potential emigration problems of the young generation, to research some opportunities for the regional university in decreasing youth emigration.

To achieve this aim, several objectives are defined:

- to interpret researchers' findings about emigration problems in Latvia;

- to carry out a survey of students about their attitude to emigration after their graduation;

- to analyse the role of regional universities in decreasing emigration processes;

- to develop proposals about opportunities for the regional university in decreasing emigration and reducing the leakage of intellectual potential from Latvia.

A hypothesis of this research is as follows: It is possible to reduce the leakage of intellectual potential from Latvia's regions by changing the strategic approach to opportunities for the regional universities, emphasizing the promotion of students' talents and abilities in a changing environment and promoting cooperation between the university and the municipality.

Research object: students.

Research subject: factors influencing the emigration of the young generation.

To achieve the objectives of this research, the following research methods were used: content analysis, analysis and synthesis, logical and abstract constructive methods, reference methods, analytic-synthetic classification, a questionnaire survey, a survey into students' opinions, the SPSS programme.

\section{Research results and discussions}

\section{Some aspects about researchers' findings related to emigration from Latvia}

Robert Barro (Barro, 1997) underlined that Human capital is a relevant source of economic growth. International migration is a pending matter not only in the EU but all over the world. Many researchers have studied emigration problems in Latvia: Eglite et al. (2002), Hazans (2003, 2011), Krišjāne, Bauls (2005, 2011), Indāns et al. (2006), Lulle ( 2007), Krišjāne et al. (2007), Krišjāne, Eglìte (2009), Hazans, Philips (2010), Bērzin̄š (2011), Mežs (2011), Dzenovska (2012) etc. 
Before the economic crisis, a sociological research study was performed by SKDS (Kaktinšs, 2006). The main question of this research was: How do Latvian people perceive migration problems? The attitude of Latvian people to the fact of emigration was analyzed. The question: "How likely is it that you in the next 2 years could go to work in another country?" with a probability of $95 \%$, was answered that $7.7-11.5 \%$ of Latvian residents, which comprised 138000 to 207000 people, in the next 2 years could go abroad. If considering how many are those who say "very important" or "rather large", then this amount could probably reach 350000 to 450000 people. The population groups more likely to leave the country to work elsewhere are people in the age group of 15-24 (45\% of the respondents). They say that the probability is "very high", or "rather high". The study also showed that $2 / 3$ of the whole population defined people emigration to work abroad as a national problem, which means this problem should be tackled at the state level.

Mežs (2006) predicted in his study the problems and perspectives in immigration policy: that by 2015 an economically active population of 200000 would have emigrated from Latvia.

The findings of a study carried out by the Hazans (2011) show that $80 \%$ of the all migrants are under the age of 35 in $2009-2011.27 \%$ out of all the migrants are highly educated and aged over 22 in 2010. The results of the survey (Hazans, 2011) showed that 65\% of the surveyed students intend to live and work abroad after their graduation.

Britain is one of the main destinations of labour from Latvia. ApsiteBerina (2013) analysed the population groups which were involved in the migration to Britain from Latvia. It was noted that in the period from 2004 to 2012, around 120 thousand Latvian nationals were officially registered in Britain. The majority of migrants were up to the age of 30 , who, according to the results of the analysis performed, burdened by debts are unlikely to return. The majority of Latvia's population in Britain, like other Eastern European migrants, can be characterized as business or economic migrants. Most of the workers are employed in Britain as unskilled labourers in spite of their high qualification and education.

"Those who talk about economic growth seem to be living in a different world than those who day after day are trying to survive. There is a mismatch between the visions of future and life experience, resulting in the loss of hope, therefore people are looking for a specific future elsewhere. Departure, no matter how difficult and heavy, however, offers some hope," said study author Dzenovska (2012). The author also stressed that emigration and diaspora life - behind the borders or in the territory of Latvia - is not merely negative and that contact with new 
challenges is evaluated in the current action and creates a new relationship, which may include new ethical and political resources to help restore the links between the Latvian public and their political space.

\section{Empirical study on the students' attitude to emigration}

The aim of this empirical study is to identify the students' view on their opportunities to remain in the native region after their graduation and to clarify the factors which influence their choice of workplace after their graduation.

\section{Methodology of the study}

The method of a survey was used. The target group was students. The sampled respondents: 100 students. It meets the pilot project. The respondents were the bachelor and master study programmes' students who studied at the Economic and Management Department of Rezekne University of Applied Sciences. By the end of their studies, students obtained knowledge and skills to start a small business or to manage different departments.

The following research methods were used: analysis and synthesis, logical and abstract constructive methods, reference methods, a questionnaire survey, a survey into students' opinion, data processing capabilities of the SPSS program, correlations were defined by Pearson's coefficients.

The year of study period: 2014 .

The hypothesis of the empirical study: regional universities have the potential to reduce the emigration of graduates by changing their accents during the study process.

\section{Results}

The questionnaire covered questions concerning the attitude of the respondents to their future prospects in the native region, their desire to go abroad or stay in the native county / region, their desired wages in Latvia after graduation and other factors.

Table 1 includes responses to the question: 'If you decide to remain in the native county after your graduation, what wage do you desire?'

Data processing (Table 1) and their interpretation reflect that $73 \%$ of the respondents concede their future prospects in their native municipality and associate their future with the native municipality after - graduation. The respondents who associate their future with their native municipality modestly appraise the desired wage: $56 \%$ of the respondents desire wages less than EUR 590, 27\% - desirewages from 
EUR 600 to 790, 17\% of the respondents desire wage of more than EUR $800.27 \%$ out of the respondents concede their future in Latvia outside their native municipality. These respondents appraise their desired wage very much alike to the respondents who associate their future with their native municipality: $52 \%$ of the respondents desire wages of less than 590 EUR, 22\% desire wages from EUR 600 to 790, and 26\% of the respondents desire wages of more than EUR 800.

Table 1 Responses of the respondents to the question about their future prospects in their native municipality and their desired wage

(Source: compiled by the author)

\begin{tabular}{|l|l|l|l|l|}
\hline \multicolumn{2}{|c|}{} & \multicolumn{2}{|l|}{$\begin{array}{l}\text { See prospects in the } \\
\text { native municipality }\end{array}$} & Total \\
\cline { 3 - 5 } & Yes & no & yes \\
\hline $\begin{array}{l}\text { Remain in the } \\
\text { native } \\
\text { municipality }\end{array}$ & wage EUR 320-590 & 41 & 14 & 55 \\
\cline { 2 - 5 } & wage EUR 600-790 & 21 & 6 & 27 \\
\cline { 2 - 5 } & wage EUR 800-1000 & 7 & 2 & 9 \\
\cline { 2 - 5 } & $\begin{array}{l}\text { wage EUR 1100- } \\
1500\end{array}$ & 4 & 4 & 8 \\
\hline & $\begin{array}{l}\text { regardless of the } \\
\text { salary }\end{array}$ & 0 & 1 & 1 \\
\hline Total & 73 & 27 & 100 \\
\hline
\end{tabular}

Only $1 \%$ of the respondents did not associate the future with the native municipality and with the entire Latvia after graduation apart from the desired wage.

Table 2 Respondents' responses to the question about their fear of risk to start a business depending on their future prospects in the native municipality

(Source: compiled by the author)

\begin{tabular}{|l|l|l|l|l|}
\hline \multicolumn{2}{|c|}{} & \multicolumn{2}{l|}{ Fear of risk } & Total \\
\cline { 3 - 5 } \multicolumn{2}{l|}{} & yes & no & yes \\
\hline $\begin{array}{l}\text { See prospects in the } \\
\text { native municipality }\end{array}$ & yes & 26 & 47 & 73 \\
\hline & no & 11 & 16 & 27 \\
\hline Total & 37 & 63 & 100 \\
\hline
\end{tabular}

Already by definition, business is related to risk. Data of Table 2 show that $35.6 \%$ of those respondents who see their prospects in their native municipalities and $40.7 \%$ of those respondents who do not see their prospects in their native municipalities have a fear of risk in starting 
a business. Overall, 37\% respondents have the fear to start their own business. The fact that $37 \%$ of the students who chose a profession associated with business management have a fear of risk requires further research. This study investigates the factors influencing the attitude to risk. Is the regional university able to influence this process?

Table 3 Respondents' self-assessment of their leadership skills depending on their future prospects in the native municipality

(Source: compiled by the author)

\begin{tabular}{|l|l|l|l|l|}
\hline \multicolumn{2}{|c|}{} & $\begin{array}{l}\text { Leadership skills are } \\
\text { missing }\end{array}$ & Total \\
\cline { 3 - 6 } & yes & no & yes \\
\hline $\begin{array}{l}\text { See prospects in the } \\
\text { native municipality }\end{array}$ & yes & 24 & 49 & 73 \\
\hline & no & 9 & 18 & 27 \\
\hline Total & 33 & 67 & 100 \\
\hline
\end{tabular}

$32.8 \%$ of the respondents who concede their prospects in the native municipality and $33.3 \%$ of the respondents who do not see their prospects in the native municipality confirmed that they miss leadership skills. In total, $33 \%$ of the respondents confirmed that they miss leadership skills.

Table 4 Respondents self-assessment of their communication skills depending on their future prospects in their native municipality (Source: compiled by the author)

\begin{tabular}{|l|l|l|l|l|}
\hline \multicolumn{2}{|c|}{} & \multicolumn{2}{|l|}{$\begin{array}{l}\text { Poor communication } \\
\text { skills }\end{array}$} & Total \\
\cline { 3 - 6 } & yes & no & yes \\
\hline $\begin{array}{l}\text { See prospects in the } \\
\text { native municipality }\end{array}$ & yes & 5 & 68 & 73 \\
\hline & no & 8 & 19 & 27 \\
\hline Total & 13 & 87 & 100 \\
\hline
\end{tabular}

$6.8 \%$ of the respondents who see their prospects in their native municipality and $29.6 \%$ of the respondents who do not see their prospects in the native municipality confirmed their lack of communication skills for starting a business. In total, $13 \%$ of the respondents confirmed their lack of communication skills, but $87 \%$ of the respondents confirmed that they have sufficient communication skills for starting a business after graduation. 
Table 5 Respondents' self-assessment of their fear of the lack of skills and knowledge to start a business after graduation depending on their future prospects in their native municipality

(Source: compiled by the author)

\begin{tabular}{|l|l|l|l|l|}
\hline \multicolumn{2}{|c|}{} & \multicolumn{2}{|l|}{$\begin{array}{l}\text { Fear of the lack of skills } \\
\text { and knowledge for } \\
\text { starting a business }\end{array}$} & Total \\
\cline { 3 - 5 } \multicolumn{2}{l|}{} & yes & no & yes \\
\hline $\begin{array}{l}\text { See prospects in the native } \\
\text { municipality }\end{array}$ & yes & 26 & 47 & 73 \\
\hline & no & 13 & 14 & 27 \\
\hline Total & 39 & 61 & 100 \\
\hline
\end{tabular}

$35.6 \%$ the respondents who see their prospects in their native municipality and $48.1 \%$ of the respondents who do not see any prospects in their native municipality considered that they lack skills and knowledge to start a business after graduation. In total, $61 \%$ of the all respondents considered that they have sufficient skills and knowledge to start a business, but 39\% of all the respondents considered that they lack skills and knowledge for starting a business after graduation (see Table 5).

Table 6 Respondents' self-assessment of feeling confident for starting a business successfully after graduation depending on their future prospects in the native municipality

(Source: compiled by the author)

\begin{tabular}{|l|l|l|l|l|}
\hline \multicolumn{2}{|c|}{} & \multicolumn{2}{|l|}{$\begin{array}{l}\text { Confidence in starting a } \\
\text { business successfully }\end{array}$} & Total \\
\cline { 3 - 6 } \multicolumn{2}{|c|}{} & yes & no & yes \\
\hline $\begin{array}{l}\text { See prospects in the } \\
\text { native municipality }\end{array}$ & yes & 37 & 36 & 73 \\
\hline & no & 12 & 15 & 27 \\
\hline Total & 49 & 51 & 100 \\
\hline
\end{tabular}

Data processing (Table 6) and their interpretation reflect that $50.6 \%$ of the respondents who see prospects in their native municipality and $44.4 \%$ of the respondents who do not see any prospects in the native municipality confirmed that they feel assured of starting a business successfully after their graduation. In total, $49 \%$ of the all respondents were convinced in starting a business successfully after their graduation.

Comparison of data in Table 5 and Table 6 allows concluding that the number of the respondents who were sure about starting a business 
successfully is smaller than that of the respondents who considered that the regional university gave sufficient skills and knowledge to start a business. This distinction is greater for the respondents who associate their future with their native municipality.

Table 7 Correlation among the factors influencing the students' choice to start a business

(Source: compiled by the author)

\begin{tabular}{|c|c|c|c|c|c|c|}
\hline Factors & & $\begin{array}{l}\text { Fear of } \\
\text { risk }\end{array}$ & $\begin{array}{l}\text { Leader- } \\
\text { ship } \\
\text { skills are } \\
\text { missing }\end{array}$ & \begin{tabular}{|l} 
Poor \\
commu- \\
nication \\
skills
\end{tabular} & $\begin{array}{l}\text { Poor skills } \\
\text { and } \\
\text { knowledge } \\
\text { for starting } \\
\text { a business }\end{array}$ & \begin{tabular}{|l} 
Confidence \\
in \\
successfully \\
starting a \\
business
\end{tabular} \\
\hline \multirow[t]{3}{*}{ Fear of risk } & \begin{tabular}{|l|} 
Pearson \\
Correlation
\end{tabular} & 1 & $.255\left(^{* *}\right)$ & $.196\left(^{*}\right)$ & -.103 & -.088 \\
\hline & Sig. (1-tailed) & & .005 & .025 & .153 & .191 \\
\hline & $\mathrm{N}$ & 100 & 100 & 100 & 100 & 100 \\
\hline \multirow{3}{*}{$\begin{array}{l}\text { Leadership } \\
\text { skills are } \\
\text { missing }\end{array}$} & $\begin{array}{l}\text { Pearson } \\
\text { Correlation }\end{array}$ & $\left..255^{(* *}\right)$ & 1 & $.235\left(^{* *}\right)$ & $-.300\left(^{* *}\right)$ & -.007 \\
\hline & Sig. (1-tailed) & .005 & & .009 & .001 & .472 \\
\hline & $\mathrm{N}$ & 100 & 100 & 100 & 100 & 100 \\
\hline \multirow{3}{*}{$\begin{array}{l}\text { Poor } \\
\text { communi- } \\
\text { cation skills }\end{array}$} & \begin{tabular}{|l|} 
Pearson \\
Correlation
\end{tabular} & $.196\left(^{*}\right)$ & $.235(* *)$ & 1 & -.126 & -.022 \\
\hline & Sig. (1-tailed) & .025 & .009 & & .105 & .414 \\
\hline & $\mathrm{N}$ & 100 & 100 & 100 & 100 & 100 \\
\hline \multirow{3}{*}{$\begin{array}{l}\text { Poor skills } \\
\text { and } \\
\text { knowledge } \\
\text { for starting } \\
\text { a business }\end{array}$} & $\begin{array}{l}\text { Pearson } \\
\text { Correlation }\end{array}$ & -.103 & $-.300(* *)$ & -.126 & 1 & -.087 \\
\hline & Sig. (1-tailed) & .153 & .001 & .105 & & .196 \\
\hline & $\mathrm{N}$ & 100 & 100 & 100 & 100 & 100 \\
\hline \multirow{3}{*}{$\begin{array}{l}\text { Confidence } \\
\text { in } \\
\text { successfull } \\
\text { y starting a } \\
\text { business }\end{array}$} & \begin{tabular}{|l|} 
Pearson \\
Correlation
\end{tabular} & -.088 & -.007 & -.022 & -.087 & 1 \\
\hline & Sig. (1-tailed) & .191 & .472 & .414 & .196 & \\
\hline & $\mathrm{N}$ & 100 & 100 & 100 & 100 & 100 \\
\hline
\end{tabular}

** Correlation is significant at the 0.01 level (1-tailed).

* Correlation is significant at the 0.05 level (1-tailed).

Data processing (Table 7) and their interpretation show that a significant correlation exists among the lack of leadership skills, the fear 
of risk, the lack of communication skills and the lack of skills and knowledge for starting a business after graduation.

The factors which influence the students' decision-making about opportunities to start a business are summarised in Table 8.

Table 8 Factors which influence starting a business

(Source: compiled by the author)

\begin{tabular}{|c|c|c|c|c|c|}
\hline \multirow[t]{2}{*}{ Factors } & \multicolumn{2}{|c|}{$\begin{array}{l}\text { Respondents who } \\
\text { associate their future } \\
\text { with their native } \\
\text { municipality (73) }\end{array}$} & \multicolumn{2}{|c|}{$\begin{array}{l}\text { Respondents who do } \\
\text { not associate their } \\
\text { future with their native } \\
\text { municipality (27) }\end{array}$} & \multirow{2}{*}{$\begin{array}{l}\text { Total } \\
\text { number }\end{array}$} \\
\hline & Number & $\%$ & Number & $\%$ & \\
\hline $\begin{array}{l}\text { Poor } \\
\text { communication } \\
\text { skills }\end{array}$ & 5 & 6.8 & 8 & 29.6 & 13 \\
\hline $\begin{array}{l}\text { Leadership skills } \\
\text { are missing }\end{array}$ & 24 & 32.8 & 9 & 33.3 & 33 \\
\hline Fear of risk & 26 & 35.6 & 11 & 42.3 & 37 \\
\hline $\begin{array}{lr}\text { Poor skills } & \text { and } \\
\text { knowledge } & \text { for } \\
\text { starting } & \text { a } \\
\text { business } & \\
\end{array}$ & 26 & 35.6 & 13 & 48.1 & 39 \\
\hline $\begin{array}{lr}\text { Confidence } & \text { in } \\
\text { successfully } & \\
\text { starting } & \text { a } \\
\text { business } & \\
\end{array}$ & 37 & 50.6 & 12 & 44.4 & 49 \\
\hline $\begin{array}{ll}\text { Lack } & \text { of } \\
\text { experience } & \end{array}$ & 61 & 83.5 & 20 & 74 & 81 \\
\hline
\end{tabular}

These factors are aggregated in case the students associate their future with their native municipality and in case the students are going to look for a job out of their native municipality after their graduation. Every thirteenth student lacks communication skills. The regional university should pay serious attention to such issues as the development of leader skills in students who study business because every third respondent lacked leader skills. $37 \%$ of the respondents feel the fear of risk. It is high due to the fact that business is always associated with risk. Consequently, these issues should be given close attention in the learning process. Critical factors are the lack of experience and the lack of confidence about the ability to start a business. In students' point of view, the lack of conviction about their ability to start a business is about $10 \%$ lower than their lack of knowledge and skills for starting a business. 


\section{Conclusions}

The results of the survey show that the majority of the students see their future prospects in their native municipality and they associate their future with their native municipality after their graduation. The job opportunities for the well-educated youth in their native regions are closely associated with the ability to develop business and the creation of new jobs in their native regions. The results of the survey of students showed the main obstacles associated with starting a business after graduation. They are as follows: lack of experience, lack of business abilities, lack of knowledge and skills after graduation, fear of risk, lack of leader abilities and lack of communication skills.

It is possible to reduce the leakage of intellectual potential from Latvia's regions by changing the strategic approach to opportunities for the regional universities, emphasizing the promotion of talents and abilities of students in a changing environment and promoting cooperation between the university and the municipality. In this context, structural changes in management and entrepreneurship study programmes should be made. Learning outcomes of these study programmes should be changed by emphasizing development of necessary skills and knowledge.

It is necessary to develop the contents of the study courses which will ensure required skills and knowledge.

The admission rules for the management and entrepreneurship study programmes should include a test which can evaluate leadership abilities of entrants.

It is necessary to strengthen cooperation between regional universities and municipalities with the aim to make students interested in their region's specialization and to involve the students who live in these municipalities in the research projects related to the interests of these municipalities.

This cooperation will allow young people to link their future with their native regions after graduation and actively participate in development processes of their native regions. It will not only reduce the emigration but will also increase the intellectual potential of the region and development of the native region as a whole.

\section{References}

1. Kaktiṇš, A. (2006). Sociologiskā pētījuma par imigrāciju prezentācija, tiešsaiste: http://providus.lv/article/sociologiska-petijuma-par-migraciju-prezentacija, skat. 15.10.2014.

2. Apsīte-Beriṇa, E. (2013). Starpvalstu migrācija Eiropas Savienībā: Latvijas iedzìvotāju migrācija uz Lielbritāniju. Promocijas darba kopsavil kums Doktora zinātniskā grāda iegūšanai ğeogrāfijas nozarē, LU, Rīga, 2013 
3. Barro, R.J. (1997). Education and Economic growth. Pieeja: http://www.oecd.org/innovation/research. skat. 12.03.2014.

4. Dzenovska, D. (2012). Pētījums: Aizbraukšana un tukšums Latvijas laukos, tiešsaiste: www.academia.edu, sk.22.11.2014.

5. Dzenovska, D. (2012) 'The Great Departure: Rethinking National(ist) Common Sense', Journal of Ethnic and Migration Studies, DOI:

6. Dzenovska, D. (2012) 'Migrācija un valstiskais redzējums: No nacionālas biopolitikas uz dzīvojamu dzivi' [Migration and the statist vision: From national biopolitics to a livable life], In Raubiško Ieva and Agnese Cimdinna (Eds), Labbūtība -dzīve - attīstība Latvijas laukos [Well-being, life and development in the Latvian countryside]. Rìga: Zinātne.

7. Hazans, M. (2011). The changing face of Latvian emigration, 2000-2010., "Latvia. Human Development Report 2010/2011: National Identity, Mobility and Capability". Riga: Univ. of Latvia Press: 70-91

8. Hazans, M. (2012). Selectivity of migrants from Baltic countries before and after enlargement and responses to the crisis.. Intra-EU Migration in Troubled Times: Skills Mismatch, Return Migration and Policy Responses. Farnham, UK: Ashgate .

9. Krišjāne, Z. (2011) Emigrācija - Latvijas jaunā iezīme, tiešsaiste: http://www.goethe.de/ins/lv/rig/kul/mag/mui/lv7543515.htm, skat. 18.02.2015.

10. Mežs, I. (2006). Latvijas imigrācijas politika:problēmas un perspektīvas. Pētījums. Latvijas ārpolitikas institūts. Konrāda Adenauera fonds, www.providus.lv, sk. 20.11.2014.

\section{REĢIONĀLĀS AUGSTSKOLAS IESPĒJAS EMIGRĀCIJAS SAMAZINĀ $\breve{S} A N \bar{A}$}

\section{Irēna SILINEVIČA}

Dr.sc.ing., Rēzeknes Augstskolas, Ekonomikas un pārvaldības fakultātes profesore, Rēzekne, Latvija

\section{Kopsavilkums}

Iedzīvotāju skaita samazināšanās tendence ir l̦oti būtiska problēma ne tikai reǵionos bet arī visā Latvijā. Pēdējos gados daudzi cilvēki no Latvijas emigrēja kā ekonomiskie bēg̣̦i uz İriju, Apvienoto Karalisti, Vāciju un citām valstīm. Vairāk nekā $30 \%$ no tiem bija labi izglītoti jaunieši, kuri bija ieguvuši augstāko izglītību Latvijā. Lielākā daḷa no viṇiem emigrācijā nodarbināti neatbilstoši kvalifikācijai. Šajā pētījumā tiek analizēta jauniešu attieksme pret iespēju pēc augstskolas beigšanas savu nākotni saistīt ar dzimto reǵionu/valsti. Pētījuma mērķis bija atklāt iespējamās jauniešu emigrācijas problēmas, kā arī regionālās augstskolas iespējas emigrācijas samazināšanā. Potenciālās emigrācijas problēmas tika noteiktas, analizējot studentu viedokḷu aptaujas, kas tika organizēta Rēzeknes Augstskolā, rezultātus. Piedāvāti priekšlikumi par reǵionālās augstskolas iespējām samazināt jauniešu emigrāciju. Tie tika izstrādāti, n,emot vērā aptauju rezultātus, kā arī sadarbības iespējas starp reǵionālo augstskolu un pašvaldību. Tiek ieteikts uzṇēmējdarbības un vadības studiju programmās ieviest izmaingas nodefinētajos studiju rezultātos un atbilstošajos studiju 
kursos, tādā veidā nodrošinot trūkstošās iemaṇas un zināšanas, kas attiecas uz uzṇēmējdarbības uzsākšanas un attīstības iespējām, kā arī uzṇemšanas noteikumos šajās studiju programmās būtu jāparedz tests, kas nosaka līdera dotību esamību. Reǵionālajai augstskolai tiek ieteikts attīstīt sadarbību ar novadiem/pilsētām, lai risinātu sekojošus jautājumus, kas attiecas uz novadā/pilsētā dzīvojošajiem studentiem, t.sk. arī topošajiem:

- $\quad$ intereses radīšana par novada speciālizācijām vēl pirms iestāšanās augstskolā;

- $\quad$ pašvaldības ieinteresētība studiju procesā, sadarbojoties ar tās teritorijā dzīvojošajiem studentiem dažādu pētījumu un izstrāžu veikšanā pašvaldības interesēs;

- $\quad$ prakses vietu nodrošināšana un atbalsts studiju procesā pašvaldības teritorijā dzīvojošajiem studentiem.

Šì sadarbība l̦autu jauniešiem pēc augstskolas beigšanas saistīt savu nākotni ar dzimto novadu un aktīvi ieklauties sava reǵiona attīstībā. Tas, savukārt, ne tikai mazinātu emigrāciju, bet arī paaugstinātu reǵiona intelektuālo potenciālu un attīstību kopumā, kā arī lielā mērā nodrošinātu jauniešu dzīves līmeṇa kvalitāti.

Atslēgas vārdi: emigrācija, reǵionālā attīstība, reǵionālā augstskola. 